\title{
Is Super-Intensification the Solution to Shrimp Production and Export Sustainability?
}

\author{
Tram Anh Thi Nguyen ${ }^{1}$, Kim Anh Thi Nguyen ${ }^{1}$ and Curtis Jolly ${ }^{2, *}$ \\ 1 Faculty of Economics, Nha Trang University, Nha Trang 625080, Vietnam \\ 2 Agricultural Economics and Rural Sociology, College of Agriculture, Auburn University, Auburn, \\ AL 36849, USA \\ * Correspondence: cjolly@auburn.edu
}

Received: 22 June 2019; Accepted: 26 August 2019; Published: 25 September 2019

\begin{abstract}
The government of Vietnam has selected shrimp production and exports as the pillars of rural economic development. The targets set depend on high yields through production intensification. International and national public research communities have raised production intensification concerns related to environmental and climate change challenges, such as saltwater intrusion, water pollution, disease outbreaks, mangrove destruction, and natural resource degradation. Social snags such as user right conflicts of water resources, food safety problems, tariff barriers, and attempts to taint the industry's image by competitors also plague the industry. These give rise to the problem of certification and questions about the influence of standards on the small-scale farming sustainability in a competitive global environment. The questions asked are, how can one bring together small-scale shrimp farmers to comply with international standards? Can small-scale shrimp farming co-exist with super-intensive producers to bring about a sustainable and competitive industry? A proposed model to horizontally organize the limited resource farmers into cooperatives to vertically integrate with large-scale firms producing shrimp using super-intensive production methods shows small-scale farmers adopting super-intensive production methods that can generate higher yields, income, profits, and is more environmentally friendly and requires less water and land. The capital requirements are high for limited resource farmers. However, with the interest showed by banks in financing models that are appropriate for small-scale farms integrated with larger firms engaged in super-intensive production systems, along with government assistance, these small-scale shrimp producing units can attain higher levels of sustainability than the open, less intensive production systems.
\end{abstract}

Keywords: super-intensive; sustainable; shrimp; production; exports; Vietnam

\section{Introduction}

Shrimp production intensification is one of the agricultural development paths, high tech agriculture innovation, chosen by the Vietnamese government to meet its millennium sustainable development goals. Vietnam is one of the world's leading producers and exporters of shrimp [1] and now ranks third in the world in terms of shrimp production [2]. The country is currently a leading exporter to Japan, Europe and the United States [3]. The success in shrimp farming has given prospects for improvement of livelihoods, income and employment to coastal and rural communities as well as the provision of much needed foreign exchange earnings to the country $[4,5]$. The Vietnamese government has promoted shrimp farming to support rural economic development. Shrimp production is a major income earner to most rural people farming on less than 1.0 ha of land and has been encouraged as a mechanism to reduce poverty, provide employment opportunities and increase exports [5]. Though shrimp production practiced under current farming systems has current farming systems has increased at a rapid rate from 2004 to 2017, there are many concerns, about the social, financial, environmental 
and economic effects of climate change, and hence about the sustainability of the practice. Climate change events endanger the structure and function, and weaken the fabric of the fragile and overly stressed coastal aquatic ecosystems on which the largest populated communities live in Vietnam. Shrimp farming which is the economic driver of rural poverty alleviation is practiced on coastal areas where vulnerability to climate change impacts is significant [6]. Climate change events give rise to temperature increases, erratic rainfall patterns, storm frequencies, sea level rise and saltwater intrusion. A World Bank [7] study concluded that a $1.0 \mathrm{~m}$ rise in sea level predicted for 2010 would likely affect $5.0 \%$ of the country's total land area, more than $7.0 \%$ of the agricultural lands and impact $28 \%$ of wetlands, $10 \%$ of the GDP, and $28 \%$ of the population. Coastal small-scale shrimp farmers are expected to suffer immensely from such climatic shifts [8]. Brauun and Casse [9] suggested an overall integrated approach for Vietnam coastal communities to manage the livelihood stresses associated to climatic change events. In this paper, we examine production intensification of shrimp production among small-scale shrimp farmers as a means of attaining sustainability, given the severity of menacing climate change events. The question posed: Is shrimp production intensification the most effective means to attain sustainable shrimp production growth under the pressures of climate change.

Shrimp farming takes place on a total surface of 700,000 hectares with two main species, whiteleg shrimp (Litopenaeus vannamei) and black tiger shrimp (Penaeus monodon), a traditional farmed species of Vietnam for many years [10]. Whiteleg shrimp entered the farming systems in Vietnam after field trials in 2002 that demonstrated high productivity, fast growth, high disease resistance and good endurance to changes in environmental conditions. Whiteleg shrimp production increased continuously and it eclipsed that of black tiger shrimp in 2013, even with lower levels of area harvested (Figures 1 and 2). However, Vietnam remains the leading producer of black tiger shrimp in the world, with an average yield of 300,000 MT per year. The Mekong Delta is the most important farming shrimp area, accounting for nearly $89 \%$ of all shrimp produced in Vietnam and harbors the top five producing provinces: Ca Mau, Bac Lieu, Soc Trang, Ben Tre and Kien Giang [11]. The development of shrimp farming in the Mekong Delta has given the region an annual average economic growth rate of $14 \%$, higher than the national average of $9 \%$ [12].

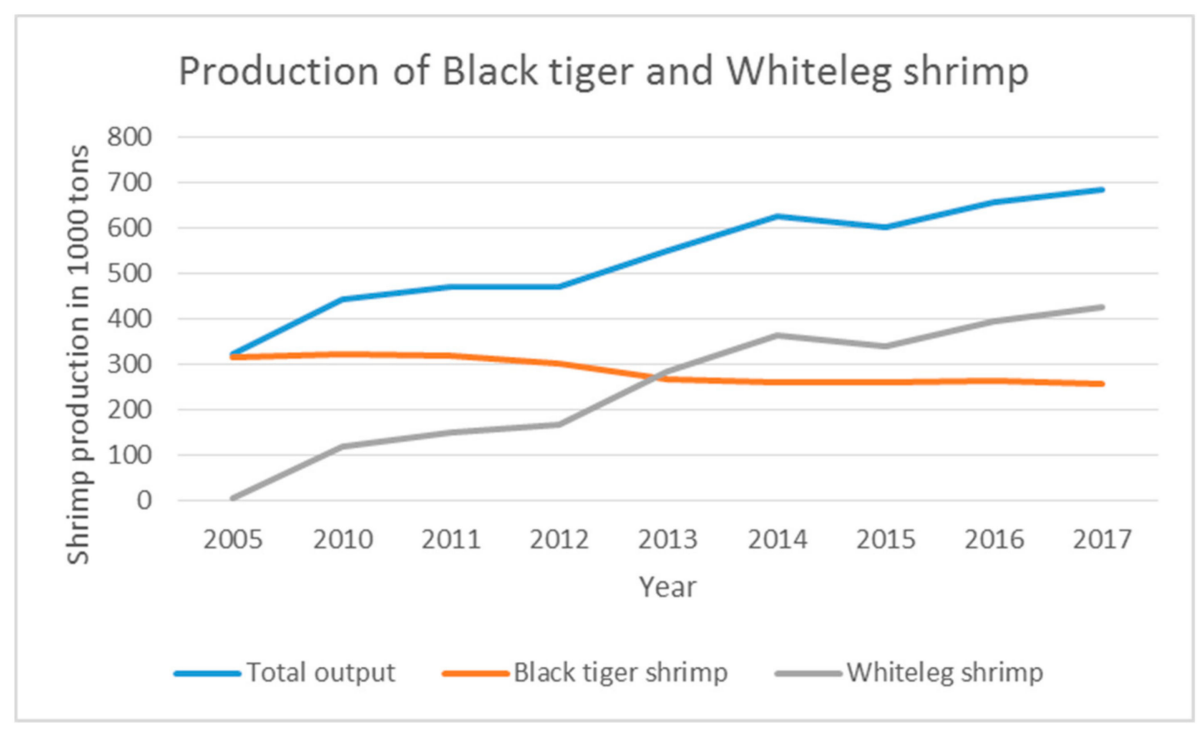

Figure 1. Production of whiteleg and black tiger shrimp of Vietnam, 2005 to 2017. 


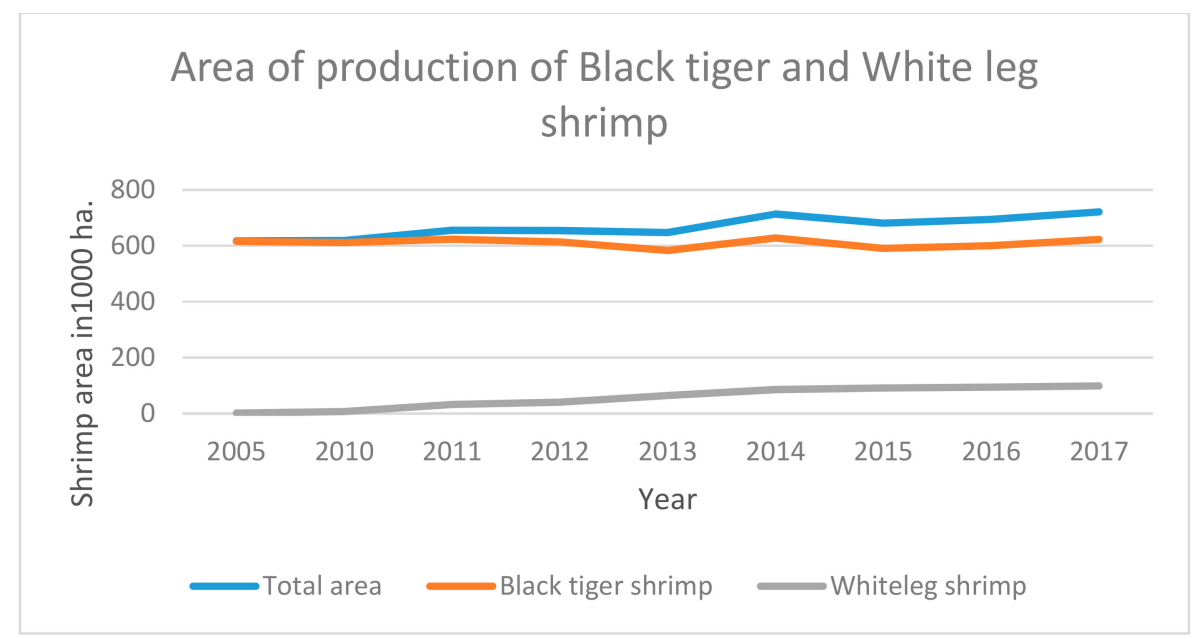

Figure 2. Area in production of whiteleg and black tiger shrimp of Vietnam, 2005 to 2017.

Shrimp production is responsible for a large part of Vietnam's seafood exports to the EU, US and Asian countries. Its market share to the EU has increased from $30.87 \%$ in 2011 to $46.64 \%$ in 2015 (Figure 3). The total shrimp exports to the rest of the world have also increased accordingly. From 2009 to 2011, the export value of shrimp increased positively from $4.5 \%$ to $24.2 \%$ [13]. Shrimp has been the biggest export product, accounting for $37 \%$ to $51 \%$ of total animal-based aquatic food exports, followed by pangasius (23\% to $31 \%$ ) [14]. In 2012 , shrimp exports decreased by $6.6 \%$ due to early mortality syndrome (EMS), also called Acute Hepato-Pancreatic Necrosis Syndrome, that reduced production. In 2013, for the first time in history, Vietnam's shrimp exports hit over US\$3 billion. A decrease in the global shrimp supply due to EMS, a rise in the global shrimp price, an increase in the demand for whiteleg shrimp and higher output of Vietnam whiteleg shrimp in 2013 were the main factors that helped Vietnam attain this target. In 2014, shrimp exports followed the upward momentum in 2013 with the growth of $26.9 \%$ to reach a peak of US $\$ 3.95$ billion. Over 10 years (2008-2017), the export value of Vietnam shrimp recorded a remarkable growth rate of 137\%. In 2017, the area and output of farmed shrimp reached the highest levels ever (Figure 1). The fluctuation of shrimp exports to the EU also raised a concern of sustainability for previous sector target [15]. In this paper, the sustainability of whiteleg shrimp production and marketing in Vietnam is evaluated as producers attempt to increase yield per ha to meet government targeted levels of exports.

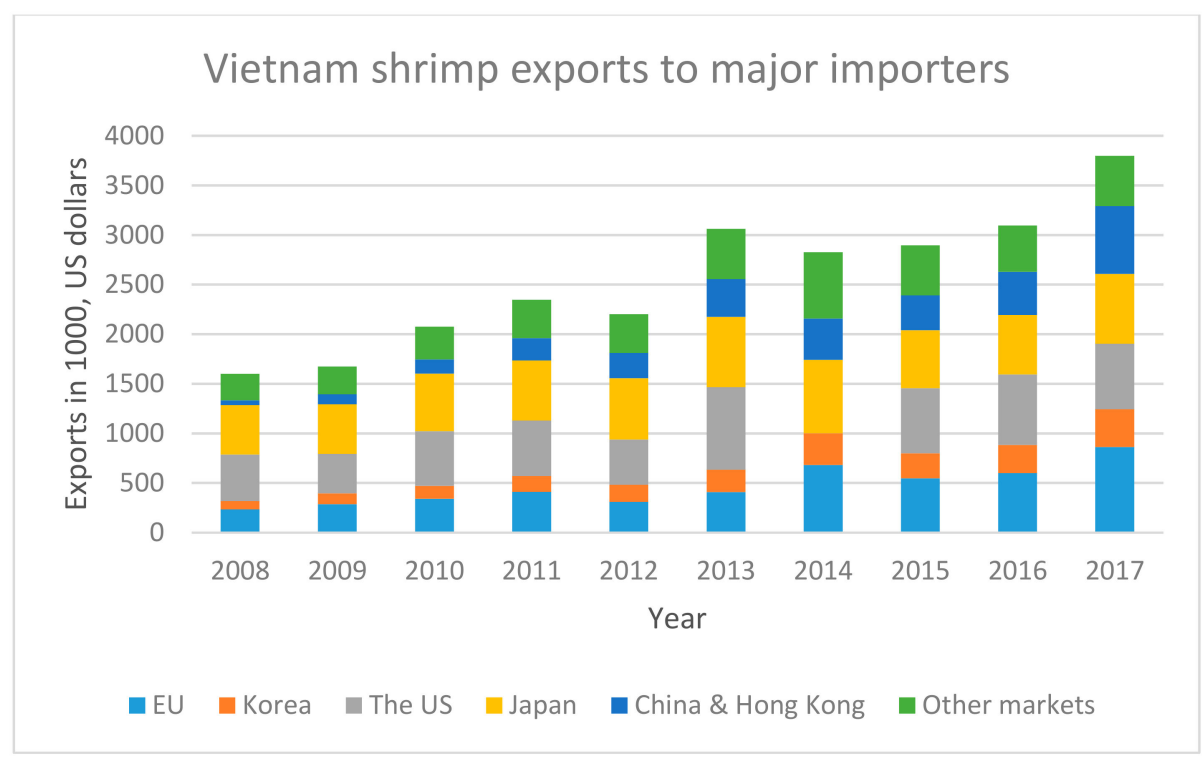

Figure 3. Export share of whiteleg and black tiger shrimp from Vietnam, 2008 to 2017. 
The targets set under the government action plan for the fisheries sector have been decided through increased production intensification and the adoption of modern technology [16]. Shrimp farming in Vietnam, however, is currently facing a number of challenges linked to production intensification and climate change events that hinder the sustainable development of the sector [13]. Disease problems plague the industry where a number of small-scale vulnerable producers supply shrimp that are of varying quality [17]. In the Mekong Delta, viral infection, including white spot syndrome virus (WSSV), monodon baculovirus (MBV), heptopancreatic parvovirus (HPV), infectious hypodermal and hematopoietic necrosis virus (IHHNV) and gill-associated nidovirus (GAV) frequently infect cultured shrimp starting at the post-larvae stage $[18,19]$. The rapid development and intensification of cultural practices have been associated with serious disease outbreaks and economic losses [20]. Black tiger shrimp in particular, but also white leg shrimp culture have been experiencing major viral disease problems, e.g., caused by White Spot Syndrome Virus, Yellow Head Virus, and Taura Syndrome Virus [21-24]. Recently, EMS has been associated with Vibrio parahaemolyticus infections, and caused up to $100 \%$ mortality in post-larvae shrimp (20 to 30 days of age) $[25,26]$.

International and national public and research communities in Vietnam have raised sustainability questions $[4,27]$. While the coastal communities in Southern Vietnam have profited considerably from the rise in shrimp aquaculture, the rapid expansion has led to serious environmental and social challenges. The negative environmental impacts from shrimp climatic change events, such as changes in rainfall pattern and temperature increases related to sea level rise, salt-water intrusion [28] are major concerns to shrimp producers. Water temperature increase, associated with changes in the hydrology and hydrographical water bodies, exacerbates the occurrence of algal blooms, which could have important impacts on aquaculture [29]. Harmful algal blooms activate toxin release into the water, reduction of dissolved oxygen concentration, spread of harmful pathogens, and threaten fish health and growth [30]. Moreover, higher water temperature increases farm costs, such as in semi-intensive shrimp farming when pumping water to maintain water and salinity levels [31]. High rainfall events on the other hand can engender reduction of water quality, high toxicity, and conditions conducive to outbreaks of infectious diseases for shrimp [32]. These claims corroborate with that of Tendencia and Verreth [29,33] and Waibel et al. [34] that the main factors affecting shrimp production and fluctuation of physical and chemical parameters of the water are variations in rainfall, temperature, salinity and $\mathrm{pH}$. These factors have also been identified as risk factors for shrimp disease outbreaks [33] associated to climate change events.

Added to these are water pollution, [35] disease outbreaks, natural resource degradation, user right conflicts of water resources, food safety problems, tariff barriers, and attempts to taint the industry's image by competitors [34,36-39]. The rapid expansion of producing areas has resulted in the loss of mangrove forests that threatens peoples' livelihoods and the ecosystem [11]. Shrimp industry development is associated with socio-economic tensions among shrimp farming communities in coastal areas of the Mekong Delta. The profitability of shrimp farming has attracted individuals with capital to invest in the industry. Intensive shrimp farming has encouraged those richer farmers and absentee owners with the capital into the business and has marginalized the poor. Hence, studies show that this industry has not been viewed as an equal access industry for all local people [36,40,41]. In Soc Trang and Ben Tre provinces of the Mekong Delta, many local famers sell land to wealthier people who come from other places to invest in intensive shrimp culture [36]. It is reported that this phenomenon is also common in Ninh Thuan province of Central Vietnam, where only 96 out of 250 shrimp farmers are locals [11,42]. Added to these pressures from developed countries, such as the US and EU, the seafood sector in Vietnam has faced a plethora of new standards over the past decade [43], some with complementary effects, that have resulted in serious changes in the food industry. The overabundance of food safety standards has left the shrimp industry management unsure of which ones to adopt and the effects on their firms. Accompanying the aforementioned challenges are the small sizes of shrimps from Vietnam to the US market. The problem of certification has triggered a number of concerns and questions about the influence of standards on the nature of 
relationships and the type of governance on sustainability of the shrimp industry in a competitive global environment. The questions asked are, how can one-harness small-scale shrimp farmers to comply with international standards given the pressures of climate change events? How can one organize these limited resource farmers to meet international standards? Can small-scale shrimp farming co-exist with super-intensive producers to bring about a sustainable and competitive industry? To address these issues, it is important to examine how to meet international standards, how to organize cooperatives as a mechanism to address required standards, to examine current shrimp farming practices, super-intensive production as a means to meet production and export targets and strategies for sustainable shrimp production and exports. This paper ends with a conclusion and a set of recommendations. It conducts a review of literature and performed secondary data analyses using graphs to answer the question: Can super-intensive shrimp production systems lead to sustainability of shrimp production with small-scale producers? The paper presents a strategy for organizing small-scale farmers to meet production targets and international product standards and certification.

\section{Meeting International Standards}

The number of standards seen in Table 1 is overwhelming for a small-scale farmer to handle. The shrimp industry in Vietnam responds to international consumers' demands, and therefore, it is buyer driven. Buyers' demands place pressure on processors and farmers to increase international food safety, quality and sustainability standards, and certification schemes. In the past 15 years, Vietnamese shrimp have been subjected to a series of food safety standards from the EU and US related to all stages of the supply chain "from pond to plate" that apply to quality, labor, and the environment. There are numerous standards imposed by various organizations that affect all aspects and actors operating along the shrimp value chain, but the most applicable standards for Vietnamese shrimp are Global Good Agricultural Practices, Best Aquaculture Practices, Safe Quality Food and Aquaculture Stewardship Council, (Global GAP, BAP, SQF, and ASC) (Table 1). Most of these standards affect all stages of the value chain and even the environmental and social aspects. However, Global GAP, BAP, and ASC include requirements for environmental protection (Table 1).

Table 1. Standards influencing various stages of the shrimp industry in Vietnam.

\begin{tabular}{|c|c|c|c|c|c|}
\hline $\begin{array}{l}\text { Specific } \\
\text { Targets }\end{array}$ & \multicolumn{5}{|c|}{ General Types of Certification } \\
\hline Chemicals & $\begin{array}{c}\text { ASC, GLOBAL GAP, } \\
\text { BAP, VietGAP }\end{array}$ & $\begin{array}{c}\text { BAP, GLOBAL GAP, } \\
\text { VietGAP, }\end{array}$ & $\begin{array}{l}\text { GLOBALGAP, } \\
\text { BAP, VietGAP }\end{array}$ & $\begin{array}{l}\text { GLOBAL GAP, } \\
\text { BAP, VietGAP }\end{array}$ & $\begin{array}{c}\text { HACCP, } \\
\text { GLOBAL GAP, } \\
\text { BAP, VietGAP }\end{array}$ \\
\hline Environment & $\begin{array}{c}\text { ASC, GLOBAL GAP, } \\
\text { VietGAP, BAP ASC }\end{array}$ & $\begin{array}{l}\text { BAP, GLOBAL GAP, } \\
\text { VietGAP }\end{array}$ & $\begin{array}{l}\text { GLOBAL GAP, } \\
\text { BAP, VietGAP }\end{array}$ & $\begin{array}{l}\text { GLOBAL GAP, } \\
\text { BAP, VietGAP }\end{array}$ & $\begin{array}{c}\text { HACCP, } \\
\text { GLOBAL GAP, } \\
\text { BAP, VietGAP }\end{array}$ \\
\hline Social & $\begin{array}{c}\text { ASC, GLOBAL GAP, } \\
\text { BAP }\end{array}$ & $\begin{array}{c}\text { BAP, GLOBAL GAP, } \\
\text { Viet GAP }\end{array}$ & $\begin{array}{l}\text { GLOBAL GAP, } \\
\text { BAP, VietGAP }\end{array}$ & $\begin{array}{l}\text { GLOBAL GAP, } \\
\text { BAP, VietGAP }\end{array}$ & $\begin{array}{c}\text { HACCP, GLOBAL GAP } \\
\text { BAP, VietGAP }\end{array}$ \\
\hline
\end{tabular}

In order to enhance the adoption of elements of all these standards and certification requirements, the government of Vietnam through the Directorate of Fisheries of Vietnam (D-Fish) decided to establish and adopt the Vietnam Good Agricultural Practices (VietGAP). To implement its strategy for sustainable development of the fisheries sector, the government of Vietnam issued Decision 1617/QĐ-BNN-TCTS on July 18, 2011, guiding the application of VietGAP standards for shrimp. This is designed to help Vietnamese shrimp exporters to minimize the difficulties in standard compliance and to meet various certification requirements in different world markets [13].

This set of standards serves as a bridge leading Vietnamese shrimp enterprises and farmers to certification of other international standards such as GlobalGAP, ASC, and others like SQF 1000. These 
international standards cover the fields of eco-system protection, food safety, social responsibility, traceability, public health and social welfare, but are numerous and likely to confuse the rural famers as to which standard to adopt. VietGAP was supposed to be a comprehensive standard that would facilitate the task of compliance with a large number of regulating bodies but instead many farmers thought that they preferred GlobalGAP and ASC because VietGAP regulations were more stringent than ASC, GlobalGAP and the other standards, and it does not provide enough market access [44].

\section{Cooperatives as an Enabling Mechanism for Meeting Standards}

The government of Vietnam has also encouraged the formation of cooperatives to enable farmers to meet the international standards requirements. In 2003, the Congress enacted a new Cooperative Law (replacing the Cooperative Law of 1996), that created favorable conditions for the development of cooperatives in most sectors. In 2012, the Congress enacted a third Cooperative Law, which became effective on July 1, 2013. Agricultural cooperatives in Vietnam increased from 9628 in 2012 to 10,204 in 2014, accounting for $54.78 \%$ of total cooperatives in Vietnam [45]. At the end of 2014, there were about 142,800 farmer groups with 1,513,027 members and 18,638 cooperatives; the number of agricultural cooperatives and fishery-agricultural service cooperatives was 10,204 [46]). By December 31, 2014, there were 1,928 agricultural cooperatives operating with 531,299 members in the Mekong Delta [12].

The cooperative has been the most popular model for organizing and linking production in Vietnamese aquaculture. However, in the development process, the old-style cooperative model showed many weaknesses, leading to the collapse of this type of model [47]. The need for linkage in production emerged again in 2016 due to the increase in market requirements, especially standardization and certification, among small-scale farmers. Certification schemes operating in Vietnam are less suitable for small-scale producers (shrimp or other species). Marschke [48] suggested that certification benefits larger producers or companies rather than small-scale producers because of the demands such as those associated with written documentation, technical requirements (equipment, wastewater treatment, feed, pond size and depth) and fees. The authors proposed guidelines to help small-scale producers cope with market demands, including a customized set of standards that are more appropriate to their size of business. However, the vast majority of small-scale producers are unlikely to change production practices with the introduction of certification schemes because they are unable to meet basic certification thresholds [49].

\section{Current Farming Practices}

Shrimp producers in Vietnam and the Mekong Delta, the principal producing area, adopt a number of farming practices ranging from large-scale extensive, improved-extensive, semi-intensive, and intensive [50]. Most of the area 337,000 ha (54.2\%) produced in shrimp in 2014 in Vietnam were under-improved or extensive farming. In second place was shrimp in rotation with rice 168,000 ha (27\%); in third place was intensive shrimp production 61,000 ha $(9.81 \%)$; then integrated mangrove shrimp production 50,000 ha $(8.0 \%)$ and finally organic shrimp 6000 ha $(1.0 \%)$. The super-intensive production occurs at its initial stages of development. About $80 \%$ of all shrimps produced in Vietnam come from farms that are less than 1.0 ha. There are no current, available statistics on production by farm sizes. However, surveys conducted in Quang Ninh, Ben Tre, Khanh Hoa and Tra Vinh provinces showed that $98.3 \%$ with a range $\mathrm{CI}(\mathrm{CI}=0.2$ to 1.0$) ; 97(\mathrm{CI}=0.2$ to 6.0$), 91.6(\mathrm{CI}=0.2$ to 1.8$)$; and 81.02 $(\mathrm{CI}=0.2$ to 4.0$)$, respectively, with a total average of $91.4 \%$ farms are less than 1.0 ha [11]. Among eight provinces, Ca Mau has the largest area (50\% of the region's total area) dedicated to shrimp farming [11]. The average size of shrimp farming land of $53 \%$ of these households was $0.5 \mathrm{ha}$, and only $16 \%$ of these households engaged in semi-intensive shrimp and intensive culture [11].

The rise of food standards in export value chains and the demand for consistent high volumes and good-quality produce/product have placed a burden on the resources of small-scale producers and are forcing them to look at possibilities of horizontal and vertical integration for survival. The required standards are difficult if not impossible to meet when a farmer has less than 1.0 ha of land. These 
requirements set limits on the farmers' capacity to comply with these standards. To meet the various standards farmers must have a waste, water pond of $0.25 \mathrm{ha}$, a pond for sludge disposal and a pond for storing water. Farmers must allow their production ponds to remain fallow for a while to minimize disease proliferation. The other point is the cost of certification. The cost of certification has become a burden to most limited resource farmers. The standards imposed on imports require costly investments that are beyond the reach of small-scale producers [51]. According to Bjørndal et al. [52], small-scale, shrimp and aquaculture producers seem powerless and face asymmetric power relationships that impact on the distribution of costs and benefits. These small-scale producers are at a disadvantage with limited capital, traditional techniques, and a dependence on family labor to manage their enterprises [53-56]. Small-scale producers who perceive themselves as powerless are likely to seek new forms of collaboration and become dependent on external sources to improve efficiency and profitability [57].

\section{Super-Intensification of Shrimp Production}

Shrimp production in Vietnam is practiced using several systems with each one having various degrees of environmental impacts. There is the extensive or traditional system in which production is based on growing shrimps within the environmental system, like among mangroves [58]. The stocking density is about 2.0 to 5.0 shrimps per $\mathrm{m}^{2}$ with intermittent feeding and simple management generating yields of 200 to $300 \mathrm{~kg}$ per hectare. Then there is the improved extensive system that is similar to the traditional system with a stocking density of 4.0 to 8.0 shrimp per square meter, where commercial feeds and water quality are carefully managed with yields of up to 800 to $1500 \mathrm{~kg}$ per hectare [59]. The semi-intensive is stocked at about 9.0 to 15 juveniles per square meter [38]. The intensive is stocked 70 to 150 juveniles per square meter and yielding 10 to 15 metric tons per hectare [60] whereas the black tiger shrimp may yield 3.0 to 7.0 tons per hectare in 100 to 150 days [59]. Super-intensive operations are "raceway" systems, as they resemble racing strips-far longer than they are wide. Avnimelech et al. [61] defined super-intensive with biofloc technology (BFT) shrimp culture as the ones that hold above 300 shrimp per $\mathrm{m}^{3}$; though higher yields are reported. VIET-UC considers super intensive stocking densities as low as 250 shrimp per $\mathrm{m}^{3}$, with BFT systems in place. Biofloc is a general term that describes an assemblage of living (bacteria, cyanobacteria, algae, fungi, protozoans) and non-living (detritus, uneaten feed, waste products) components that form suspended aggregates also in aquaculture systems. The system uses less land area and water. The density of the shrimp populations in super-intensive systems requires constant and careful water quality monitoring. The government of Vietnam has stated that super-intensive production is the way forward to increase production and meet projected national export targets.

Extensive or traditional systems, with lowest yields are gradually being replaced by improved extensive, semi-intensive and intensive systems. Shrimp production in extensive, improved extensive, semi-intensive, and intensive systems in Vietnam, takes place outdoors [62]. The improved extensive and semi-intensive are considered environmentally friendly and promoted as systems to remedy the problems associated with intensive farming systems. The government of Vietnam, however, is emphasizing increased production through increases in the yields of shrimp and therefore the question is can extensive, improved-extensive, and semi-intensive farming at a lower level of intensity using more natural systems enable the country to attain its production and export targets with significant reduction in environmental impacts? Aquaculture production studies are divided between those that find low-intensity shrimp farming environmentally superior to intensive production $[63,64]$, and those that report that the land-sparing effects and efficiency gains of intensification minimize a variety of negative impacts $[65,66]$. Cao et al. [63] concluded that semi-intensive shrimp farming in China resulted in lower global warming, acidification, eutrophication impacts, and energy and biotic resource use than intensive or super-intensive production. Henriksson et al. [67], on the other hand, found that the eutrophication and ecotoxicity impacts of semi-intensive shrimp farming in Vietnam were greater than intensive shrimp farms. As a result, we hypothesize that impacts of aquaculture intensification will be multidirectional and will involve trade-offs among different impact categories under climate change conditions. 
Criticism of intensification of shrimp farming systems focused on high material and energy inputs, and more effluent discharge. Based on higher land footprint, however, intensive systems might outperform extensive, improved extensive and semi-intensive systems in land modification [68]. By isolating the culture environment from the surrounding ecosystem, closed recirculating systems are designed to grow shrimp at high densities with zero discharge of effluents. Water treatment removes toxic wastes and is then reused. Reusing water gives farmers better control over the environment, and reduces water consumption and effluent discharge [69]. Notable advantages of recirculating systems also include improved waste management and better control of the disease introduction into the systems through the reuse of polluted water.

According to a new study conducted by World Wildlife Fund in Vietnam and Thailand [70] more intensive, shrimp farming can yield better environmental and economic results than its alternative extensive or improved extensive systems. Previous greenhouse studies conducted in Brazil by Krummenauer et al. [71], using L. vannamei support these claims that higher shrimp yields are obtainable with super-intensive shrimp production. However, high stocking densities result in rapid nitrogen, compound waste accumulation [72-74]. High concentrations of these wastes are toxic to the shrimp $[64,65,75-78]$. Contrarily, researchers have found that in exchange culture systems these wastes can be easily eliminated [79-81]. Research conducted by Krummenauer et al. [82] showed that the use of same water over multiple culture cycles using BFT can be beneficial to L. vannamei growth rate stocked at 312 juveniles $/ \mathrm{m}^{3}$. Thus, the economic success of a given culture system depends on the balance achieved between production of wastes and the assimilation capacity $[83,84]$. The application of BFT systems combines removal of nutrients from the water with production of microbial biomass. The inclusion of the microbial biomass waste generated into the production system can provide an additional nutritional source for shrimp [85-90]. The experimental results by Krummenauer et al. [82] showed that a significantly lower concentration of ammonia was observed at a density of $450 \mathrm{shrimp} / \mathrm{m}^{2}$ $(0.19 \mathrm{mg} / \mathrm{L})$, whereas nitrite was higher at a density of $300 \mathrm{shrimp} / \mathrm{m}^{2}(1.33 \mathrm{mg} / \mathrm{L})$. Nitrate concentration did not significantly differ among treatments. Phosphate concentration was lower at a density of $150 \mathrm{shrimp} / \mathrm{m}^{2}(0.87 \mathrm{mg} / \mathrm{L})$ and differed significantly from the values found at densities of 300 and 450 shrimp $/ \mathrm{m}^{2}$. Dissolved oxygen decreased throughout the experimental period [91].

A study in Vietnam and Thailand showed that, in most cases, intensive operations used land much more efficiently, yielding at least eight additional tons per hectare. They also reduced the costs of land use by more than $90 \%$ per kilogram of shrimp. The most intensive farms made more, efficient use of energy as well, with energy costs that were $74 \%$ to $89 \%$ lower than the least intensive operations [92]. By producing more shrimp per hectare of land, farmers can increase production to meet growing demand for shrimp without increasing pressure on the region's natural resources [93]. Intensification can also have negative implications as well as concentrated wastes in effluent and the potential to stress shrimp to the point that disease outbreaks occur if such wastes accumulate too quickly. However, poultry producers that incorporated new technology through intensification, biosecurity programs and the development of higher quality and lower cost feeds resulted in increased predictability of production, increased production levels, and decreased production costs that allowed the adopters to flourish and be profitable.

The technology adoption is, however slow by enterprises, and operated mainly by research institutions [94]. The dominant reason for this is that cost of production is substantially high and the investment requirements are still above the means of limited resource farmers. Hanson et al. [95] provided an overview of economic factors influencing the profitability of super-intensive BFT systems in the US. The authors found that the biological improvement through the increase of survival rate could lower production costs. A $20 \%$ increase in survival was capable of decreasing production costs by 0.80 USD per $\mathrm{kg}$. The improvement in consistency in production could increase the profitability of the system. Some of the problematic biological issues include poor growth rate, an inability to maintain adequate $\mathrm{pH}$, likely due to high rates of microbial respiration, high $\mathrm{CO}_{2}$ concentration, and bacterial infections in animals [96]. Some of the mechanical issues include pump failures and oxygen supply and system failures. 
One of the main problems in super-intensive cultures is rapid water eutrophication resulting from increasing concentrations of nutrients and organic matter during the culture period [83]. Production systems of this kind, commonly referred to as biofloc production systems, use mainly the heterotrophic nitrification bacterial processes, working with carbon nitrogen $(\mathrm{C} / \mathrm{N})$ ratio via the addition of external carbon sources, such as molasses, to the ponds [97]. According to Cohen et al. [81], the increase in ammonia values relates to the retarded development of nitrifying bacteria or the increase of phytoplankton abundance. This nitrification pathway alone is not sufficient to digest all the nitrogen involved in a shrimp pond with zero water exchange. On the other hand, the control of the water quality, via the control of nitrogen accumulation and the use of high quality probiotics and immune-stimulants, greatly reduces the environmental stress on the animals. However, variation in ammonia concentration in BFT cultures is apparently a natural phenomenon and has limited impact on growth and survival of shrimp [98]. The direct consequences of this phenomenon are a reduction in the size variation at harvest.

\section{Strategies for a Sustainable System}

To ensure social, environmental and economic sustainability of the shrimp industry, given the fragmentation of small-scale producers, the imposition of standards by exporters, the possible disease threats and the investment requirements for any major changes in farming practices due to climate change, we propose a model that would enable the regrouping of farmers, assist them in sustainably increasing production and meeting international standards. The proposed model requires institutional support, more investment, horizontal and vertical integration with larger lead firms, and the careful monitoring of production practices and the use of water. The model also requires support by the private sector, banks and credit institutions, research and extension service, and changes in the governance structure of the industry (Figure 4). We will first begin by examining the institutions and their role in organizing the farmers to meet international standards.

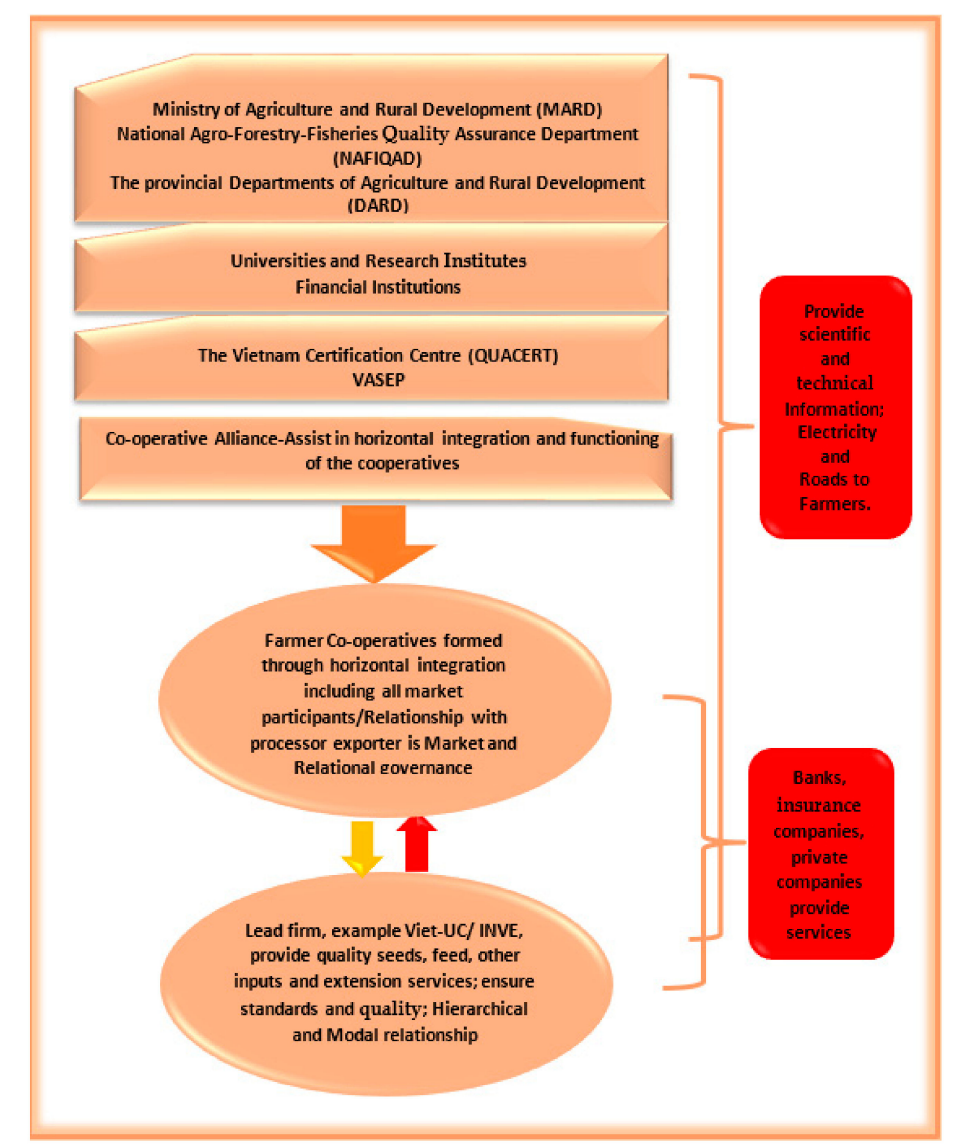

Figure 4. Small-scale farmers, adoption model of shrimp production super-intensification. 


\subsection{Institutional Framework}

The government of Vietnam is the main supporting agent and is responsible for the legal and regulatory framework for the development of the shrimp industry, managed by the Ministry of Agriculture and Rural Development (MARD)) [40] (Figure 4). At the local government level, the Department of Agriculture and Rural Development (DARD) is in charge of implementing and expanding the decrees and regulations to other relevant departments, lower management authorities, processing/export firms, and farmers.

In addition, the Provincial Trade Promotion Center and the National Trade Promotion Center explore new export markets. The National Fisheries Quality Assurance and Veterinary Directorate lend support to the industry in the form of checking, controlling and certification [99]. International NGOs are involved in supplying information on food safety standards and feed quality to producers [100,101]. The Vietnam Shrimp Association (VSA) is a social-professional entity established to support the sustainable development of the shrimp industry. Universities and research institutions participate in supplying research information through local extension services. VASEP supplies processors and exporters with information and training on quality and safety requirements. The main roles of VASEP are to propose policies for promoting the growth of the fisheries sector; to support enterprises in improving productivity, quality, and efficiency in production and business; to provide up-to-date information and data on the seafood market; and to organize and implement training activities and trade promotion.

MARD has a mandate to administer to agricultural cooperatives at the state level. In each region, the People's Committee (local authority) is responsible for administrative functions at the city and provincial levels $[102,103]$. The Vietnamese Government established the Cooperative Alliance in October 1993 and it represents and protects the rights and interests of cooperatives, cooperative federations, and members who voluntarily participate in building and developing the cooperative economy in Vietnam. The Cooperative Alliance is responsible for assisting in the organization and early functioning of the cooperatives.

The proposed model requires the development of linkages between cooperatives and private enterprises like VIET-UC/INVE through the encouragement and supervision by MARD provincial representatives and the Vietnamese Cooperative Alliance [46]. VIET-UC is a large-scale, intensive shrimp farm in Vietnam. VIET-UC's approach to intensive, large-scale farming results in higher densities, increased harvest volumes and better and cleaner shrimp. The company wants to show that with adequate investment and better management, intensive farming systems can result in better products, higher market prices and an improved image for Vietnam's shrimp products. INVE Aquaculture is working closely with VIET-UC's management team to optimize its operations and protocols. This type of linkage could assist cooperative members to adopt farming practices that comply with VietGAP or GlobalGAP regulations and the requirements of other certification bodies. Such connections would allow the sourcing of quality inputs and the adoption of farming practices that would enhance yields and production standards.

\subsection{Horizontal Integration}

Cooperative groupings through a process of horizontal integration can enable farmers to source inputs in the form of a market and or relational style of governance and work together to reduce costs. Horizontal integration in the form of cooperatives empowers farmers to meet standards requirements [104]. Hence, in order to achieve certification, producers are encouraged to form cooperatives $[105,106]$. The rationale is that group certification lessens the burden on individual producers as well as certifiers, and potentially helps reduce complexity and avoid lengthy value chains common to small-scale shrimp production in Vietnam [26]. With group certification, small-scale producers can keep their own farms, rather than being forced to acquire more land or leave aquaculture. The Southern Centre for Agricultural Policy and Strategy [107] believed that cooperatives or farmer clusters could enable horizontal integration that would improve the capacity of small-scale producers 
to comply with international and national production standards, and in turn improve their vertical access to international markets $[38,105]$. Cooperative production is generally envisaged as a means of improving the poor economies of scale that limit small holders' capacity to improve product quality, bargaining power, capital investment, and management skills [5,105,108]. Marschke and Wilkings [48], on the other hand, in response to the problem that aquaculture standards are not appropriate for small-scale producers, suggested a separate national standard customized specifically for small-scale producers in Vietnam's aquaculture sector. These cooperatives enable them to vertically integrate and develop a relational governance style with the large input providers like VIET-UC.

\subsection{Vertical Integration}

Vertical integration allows the small-scale limited resource farmers to be socially sustainable in that each firm remains as a business entity in making decisions and participate indirectly through their votes in the governance structure of the value chain. VIET-UC as the lead company promised to supply the inputs and ensure that the cooperatives are adhering to the VietGAP standards that globally include regulations by the other certifying bodies. VIET-UC will then develop a captive or hierarchal relationship with the small businesses. Indirectly, the larger company has an overall sight control over several production or distribution steps involved in product sales and marketing. The cooperatives can then relate their concerns about the effect of consumer standards on the production process forward to importers.

Viewing the benefits helps enterprises understand the importance of integration in a supply chain: First, a close alignment and coordination between organizations helps improve the efficiency of all members in the supply chain. It allows for solving common problems efficiently and effectively. Any uncertainty in the supply chain causes participating organizations to react slowly to changing conditions. Secondly, integration can improve the quality of the flow in the supply chain. Flow of material is moving faster and more reliably in a supply chain. Profits are shared for all participants. Information flow is shared and open to everyone.

The increase in yield is possible with the dissemination of best management practices encouraged by the private enterprise, and MARD's extension service monitors farmers' behavior. The distribution avenue to local consumers remains unchanged, but with one exception: The marketing is through the same cooperative structure that absorbs all collectors, financial supporters, and others as members. The guidelines for membership specified in the Cooperative Law permit such inclusion [102]. This means that collectors are encouraged to be part of the cooperative and assist the cooperative members in adherence to standards and in seeking markets and reasonable prices for a quality product, at the same time facilitating vertical integration and increasing shared farmer governance. The product directed to the export channel goes through the cooperative to the processors. This type of organization has several positives, in that it shortens the distribution channel, facilitates product traceability, reduces transaction costs, and allows the cooperatives to integrate vertically backward with private enterprises such as VIET-UC and forward with processing plants. Small-scale shrimp farmers as well as medium- and large-scale ones can benefit from economies of scope as the cooperatives sell to various market segments.

\subsection{Super-Intensification and Land Use}

\subsubsection{Land and Water Use}

The use of white leg shrimp in production intensification in Figures 1 and 2 shows that in 10 years (2008-2017), the area and output of black tiger shrimp decreased and then increased at a decreasing rate while the area and output of white leg shrimp increased at an increasing rate. In terms of area, the area of black tiger shrimp farming increased by $1.8 \%$ while the area of white leg shrimp farming rose sharply by $1286 \%$. In terms of output, black tiger shrimp production decreased by $20.9 \%$ while white leg shrimp production went up $256.7 \%$ [13]. One should remember that white leg shrimp are 
produced mainly using intensive practices whereas black tiger shrimp are produced in most cases under extensive production as well as intensive systems [109]. The growth rate of output was higher than the growth rate of the area because farmers and enterprises increasingly applied scientific and technological advances to shrimp farming, using new well-developed seedlings and advanced farming models from abroad to increase production on the same farming area [13]. Hence, rapid increase in production is associated to intensification rather than surface area expansion. Therefore, the call for increased production through intensification also suggests that production intensification is a sustainable way to improve production without necessarily increasing land or water use.

The study by Krummenauer et al. [71] showed that L. vannamei was ideal for production intensification. The increase in production intensification requires less land and less water, an appropriate adaption to climate change events, since the expectation is that water recirculation is obligatory [70]. In terms of disease control with highly monitored water recirculation system there is better control of disease. The disease problem is more frequent with contaminated water and sedimentation of toxic material. The removal of sedimentation is possible with the construction of a system that filters out the waste used in the production of biogas for electrifying the system.

\subsubsection{Disease Control under Super-Intensive Methods}

Disease outbreaks have been the primary cause of shrimp production loss during the last two decades [110]. Polluted water often causes shrimp disease proliferation in the pond itself. Most of the wastewater and contaminated sediment from shrimp ponds are discharged into receiving waters. This, however, is the source of water for other shrimp ponds. Without proper treatment, the pathogens from infected ponds are likely to spread to other ponds. Breeding stock in inappropriate conditions also enhances the risk for disease epidemics. When the diseases can be detected, they are difficult to control because of poor regulation, and the 'open' nature of land and water resources.

Market participants have promoted Biofloc technology (BFT) as the means of reducing the toxicity and disease spread in pond waters [111]. The basic principle of the BFT system is to recycle waste nutrients, in particular nitrogen, into microbial biomass that is usable by cultured animals or be harvested and processed into feed ingredients. Biofloc may enhance immune activity based on mRNA expression of six immune-related genes- $-\mathrm{ProPO}_{1}, \mathrm{ProPO}_{2}, \mathrm{PPAE}$, ran, mas and SP1 [112]. The application of BFT brings about beneficial effects in disease control and management in shrimp culture [113]. In addition to the advantages of BFT, Crab et al. [114] have shown that BFT constitutes a possible alternative measure to fight pathogenic bacteria in aquaculture. Intensive aquaculture of shrimp is one of the most promising sectors in aquaculture production and its use is of growing interest to farmers [115]. Despite its huge success, shrimp culture is facing severe outbreaks of infectious diseases that have caused significant economic losses in the Mekong area.

Biofloc systems have demonstrated the ability to maintain ammonia below toxic levels and to improve the feed nutrient utilization efficiency of the cultured animals, but also to provide extra nutrients and exogenous digestive enzymes. Biofloc application can also lead to increased growth, survival and reproductive performance of the cultured animals [61,114]. The promotion of BFT is a means of encouraging super-intensive shrimp production but it still cannot be successful without careful monitoring of the water quality.

\subsubsection{Climatic Adaptation}

Whiteleg shrimp production farms are highly affected by disease outbreaks; however, intensification through technical investments and increased biodiversity could reduce the vulnerability of shrimp farmers to disease outbreak [116] related to extremes in rainfall and temperature fluctuations. Therefore, technology transfer mechanisms and better management practices applicable to small-scale farming systems must reach all farmers [29]. A majority of the local experts claimed that shrimp diseases occurred more frequently in extensive or improved extensive shrimp farming than intensive or super-intensive shrimp farming due to exposure to climatic events. The above claim matches with [117] 
that there were more WSSV occurrence in improved-extensive farming than in semi-intensive farming because WSSV populations on extensive farms would be more stable over longer periods of time [118]. However, the viruses in the more intensive systems are more virulent [118]. Therefore, the virus present in extensive and improved extensive systems may show signs of infection, but the outbreaks are more deadly in the intensive systems, which is also because of the higher density.

Supporting the intensive system benefits, Tendencia et al. [119] claimed that it could minimize shrimp disease risks because of less exposure to the vagaries of the climate and weather. This is consistent with studies showing that technological investments in intensive system lessen the risk in shrimp farming and reduce vulnerability to disease outbreak [119]. However, scientists have argued that shrimp households practicing intensive systems with a higher input, results in significantly more income, they also face a high risk associated with shrimp mortality [120]. The work of Ha et al. [121] and $\mathrm{Ha}$ [122] also supports the above authors' findings that the intensive system was vulnerable because of more frequent harvest failure, fluctuating shrimp prices, and market competition. Quach [123] research suggested that climate change events such as flooding, saltwater intrusion, changes in temperature and acidification affected all types of shrimp farming systems. However, from an income standpoint, climate change had greater negative effects on the less intensive shrimp farming systems. The reasons provided for this were that farmers engaged in intensive shrimp farming had greater adaptive capacity and higher rates of literacy. Quach et al. [124] therefore, suggested shrimp farming intensification, integration, and increased farmer cooperation as key adaptation options to future climatic change events in the Ca Mau province and Vietnam.

\subsubsection{Capital Requirement}

Investment capital for super-intensive system is substantial for limited resource farmers. However, there are young entrepreneurs who are already building systems on 1.0 ha that costs USD 25,000.00. These systems can be stocked at 250 juveniles $/ \mathrm{m}^{2}$, producing 3.0 to 4.0 crops per year and generate net revenues of USD $\$ 300,000$ per annum. These are in the trial stages of testing but banks are closely observing these for funding. These systems would require the support of the private sector, banks, and other supporting services working in tandem with the small growers to ensure smooth running and the economic and environmental sustainability of the system.

\subsubsection{Economic Sustainability}

Experimental results obtained by Hanson et al. [95] show that for a 10-year super-intensive system, the net present value was positive and the internal rate of return was $11.72 \%$. This was based on an FCR of 1.59 for a $4.7 \mathrm{~g}$ shrimp growing to a $27.22 \mathrm{~g}$ in 77 days. In a study conducted by Quagrainie, [125] in Indiana indoors with a stocking density of $450 / \mathrm{m}^{3}$ profitability of Pacific white shrimp (L. vannamei), the cost depended on the level of mortality. Shrimp farmers could only make positive profits if the shrimps were produced and sold at 36/30 counts.

The first couple of trials conducted by private companies, VIET-UC and INVE were designed to secure the farming targets using zero water exchange protocols, first experimentally and then commercially [126]. Subsequent success of those several runs followed to increase farming outputs with higher stocking densities. Field trials conducted by VIET-UC and INVE on a larger scale than green-house trials showed that with a stocking density of 250 juveniles $/ \mathrm{m}^{2}$, the farming process results in the production of $20 \mathrm{~g}$ shrimp in 90 days, with a survival rate of $75 \%$ and a resulting FCR of 1.3 . At 500 juveniles $/ \mathrm{m}^{2}$ the shrimp reached an average size of $20 \mathrm{~g}$ in 100 days; at 700 juveniles $/ \mathrm{m}^{2}$ the shrimp reached $17 \mathrm{~g}$ in 100 days. To date, the optimal economic output of the INVE protocols applied at VIET-UC resulted from a stocking density of 250 juveniles $/ \mathrm{m}^{2}$. Considering the complete absence of water renewal, and the indoor production, the impact of environmental variables caused by the meteorological events is greatly reduced, resulting in optimal consistency of the results shown above for the different experimental and commercial trials realized. The stocking of $200 \%$ more shrimps (cf. 500 juveniles $/ \mathrm{m}^{2}$ ) resulted in a productivity increase of only $+150 \%$. The growth, survival and FCR 
differences between stocking density are minimal $(<5 \%)$; the results show lower economic return on the investment, even with increased productivities. The main factors responsible are the increase in both the juveniles cost and the feed cost, and the longer production time [127].

The development program of VIET-UC also includes social projects to help small farmers in Vietnam achieve more consistent production via the use of VIET-UC genetically selected PLs, high quality improved feed, and technology transfer including on-site support. INVE will continue assisting VIET-UC in these developments, with the shared goal of making shrimp farming a more sustainable activity than it is today.

\section{Conclusions}

Shrimp farming has been explicitly encouraged by the Vietnamese government and local authorities, with the promulgation of government resolution allowing transformation of low productivity rice/salt fields into shrimp aquaculture [4,127]. Recent calls for sustainable intensification of food production $[2,128,129]$ indicated an increased understanding of the potential environmental-economic-social benefits of intensification on sustainable production and exports of shrimps. The Vietnamese Government aims to guide the country to become a leading global seafood exporter by placing emphasis on shrimp production intensification, value chain efficiency improvement, certification and standards enforcement, and risk reduction. Government of Vietnam based production targets of high quality shrimp on the output of a large number of fragmented farmers dependent on government assistance for protection against disease failure, climatic and industrial shocks [17]. The only way to achieve increased control in the supply chain is to create a competent base of suppliers who are not too risky to work with lead firms, or by creating cooperatives for small-scale farmers that are not completely dependent on government handouts or credit systems. This endeavor will enable the small-scale producers to empower themselves through the formation of cooperatives, to buy farm inputs and develop vertical linkages with larger enterprises while maintaining a bargaining position that enables them to engage in direct relations with shrimp exporters [38]. The small-scale producers will then solicit assisted technological systems for production enhancement through vertical integration with larger and more advanced firms. These improved technologies in this case involve the production of shrimps using super-intensive methods of production with reduced environmental effects. The major question is can super-intensive production be the driver towards shrimp production sustainability with the high levels of natural resource use, potential environmental degradation, menacing climatic changes and income inequality related to production intensification.

The aquaculture industry has itself been wrestling with those many insurmountable problems inherent in the so-called "open production systems," that is the traditional, extensive, semi-intensive and intensive production models. The problems stem from the fact that these present-day methods of shrimp aquaculture pollute and degrade their surrounding environments, while at the same time depending on a healthy state of natural resources to maintain their own production [113]. This reliance on the health of the external environment, such as the sea and fresh water sources, while at the same time degrading these very vital supporting systems with massive amounts of toxic effluents, classifies these self-degenerative open-cycle production schemes as "throughput systems." Biofloc is a closed system that presents an alternative promising technology for stable and sustainable, self-nitrification process within culture ponds with zero water exchange [130].

The "closed-system" potentially eliminates many of the obvious failures of the modern "open-production system," by operating in a more environmentally "friendly" fashion. Recirculating production pond waters that remove toxins from these fouled waters are essential for the proper functioning of the system. Recycling of the effluent waters emanating from the production ponds is possible in various ways, ranging from complex and costly water filtration systems to the establishment of settlement ponds, or integrated secondary containment ponds [131]. The use of recirculating system encourages the proliferation of microbial activities that enables higher levels of uniform shrimp. Biofloc can generate yields as high as nearly $50 \mathrm{mt} /$ hectare/cycle under research environments, but commercial 
scale production of $20-25 \mathrm{mt} / \mathrm{ha} /$ cycle is normal [130] compared to 3 to 5 tons per ha per cycle commonly obtained in the Mekong Delta.

There is hope that such an innovative closed-system in an aquaculture enterprise will succeed, where the open-cycle systems have so miserably failed. Water quality is obviously a major concern of any aquaculture facility, and elimination of antibiotics, pesticides, and fertilizers will help alleviate one of the major contributing factors leading to water quality declines during production. Improved feeds and feeding regimes are also important considerations in water quality control, as is regular careful monitoring and assessment of the internal pond environment. All of these factors are taken into consideration.

Changes in the prevalence and distribution of viral diseases of fish and shrimp, improved surveillance, the availability of new cell lines for virus isolation and characterization, the development of more sensitive molecular diagnostic methods, enhanced testing activity in natural ecosystems and greatly improved aquatic animal health diagnostic capability in some developing countries contribute to disease risk reduction. For some viral pathogens, the availability of improved detection and surveillance capabilities has resulted in reports of a greater host or geographic range than previously known.

\section{Recommendations}

If Vietnam succeeds in organizing its farmers into competent cooperatives that are able to engage with larger firms like VIET-UC/INVE into the supply of inputs, supervision and techniques of production intensification; then small-scale farmers stand a good chance of convincing exporters to invest in sustainable relationships with them. This can enable GOV to attain its set export targets [132]. In order to realize these goals of environmental, social and economic sustainability of the shrimp industry, MARD should:

1. Encourage small-scale farms to integrate horizontally into cooperatives that will afford them social sustainability as they remain as individual owners and managers of their enterprises while complying with VietGAP regulations.

2. Encourage VIET-UC and similar large companies to integrate vertically with small-scale farmers to help them increase production through the adoption of super-intensive production system and enhance the industry's environmental sustainability through the reduction of land and water use in its production system.

3. Encourage the participation of the private sector and banks to support and provide loans to the small-scale farmers based on the use of more relevant credit worthiness indicators so that they can engage in super-intensification of production and increase their net revenues in order to become more economically sustainable.

4. Also, encourage universities and the extension service to increase their participation and engagement in research and information diffusion that benefit small-scale farmers.

5. Review planning, improving irrigation infrastructure, electrical grids, and transport systems to facilitate the participation of all farm types.

Funding: This research received no external funding.

Acknowledgments: The authors would like to thank the ClimeFish Project financed by The European Union's Horizon 2020 research and innovation programme under grant agreement No. 677039 and the NORHED Project (QZA-0485, SRV-13/0010) for their support in the preparation of this paper.

Conflicts of Interest: The authors declare no conflict of interest.

\section{References}

1. Ministry of Agricultural and Rural Development (MARD). Ministry of Agricultural and Rural Development Internal Meeting on Coping Drought and Salinity Intrusion in Mekong River Delta; Soc Trang', Ministry Report; MARD: Hanoi, Vietnam, 2017. 
2. FAO. The State of World Fisheries and Aquaculture: Opportunities and Challenges; Food and Agriculture Organization of the United Nations: Rome, Italy, 2016.

3. Nguyen, T.A.T.; Bui, C.T.P.N.; Jolly, C.M. The value chain of exported whiteleg shrimp: Case study in Khanh Hoa province, Vietnam. Int. J. Food Agric. Econ. 2017, 5, 9-23.

4. Tran, V.L.N.; Le, T.L.; Trinh, Q.T.; Pham, M.T.; Tran, T.A.N. Vietnam Shrimp Farming Review. Individual Partner Report for the Project: Policy Research for Sustainable Shrimp Farming in Asia; European Commission INCO-DEV Project PORESSFA No.IC4-2001-10042; CEMARE University of Portsmouth UK and RIA: Bac Ninh, Vietnam, 2002; 19p.

5. Ha, T.; Bush, S.; van Dijk, H. The cluster panacea? Questioning the role of cooperatives in shrimp aquaculture in Vietnam. Aquaculture 2013, 388, 89-98. [CrossRef]

6. Handisyde, N.T.; Ross, L.G.; Badjeck, M.-C.; Allison, E.H. The Effects of Climate Change on World Aquaculture: A Global Perspective; Department of International Development, GIS Modelling and Spatial Analysis for Aquaculture: London, UK, 2014; p. 151.

7. World Bank. Vietnam-Economics of Adaptation to Climate Change; The World Bank Group: Washington, DC, USA, 2010.

8. Bell, J.D.; Ganachaud, A.; Gehrke, P.C.; Griffiths, S.P.; Hobday, A.J.; Hoegh-Guldberg, O.; Johnson, J.E.; Le Borgne, R.; Lehodey, P.; Lough, J.M.; et al. Mixed responses of tropical Pacific fisheries and aquaculture to climate change. Nat. Clim. Chang. 2013, 3, 591-599. [CrossRef]

9. Bruun, O.; Casse, T. On the Frontiers of Climate and Environmental Change; Vulnerabilities and Adaptations in Central Vietnam; Springer: Berlin/Heidelberg, Germany, 2013; ISBN 10:9783642358036.

10. VASEP. Vietnam Whiteleg Shrimp Exports to Go on the Rise in 2018. Available online: http://seafood.vasep. com.vn/seafood/50_12532/vietnam-whiteleg-shrimp-exports-to-go-on-the-rise-in-2018.htm (accessed on 4 June 2019).

11. Lan, P.T.N. Social and ecological challenges of market-oriented shrimp farming in Vietnam. SpringerPlus 2013, 2, 675. [CrossRef] [PubMed]

12. Ha, T.T.T. The changing role of the state in shrimp farming governance in Mekong Valley, Vietnam. J. For. Sci. Tech. 2016, 5, 142-148.

13. VASEP. Report on Vietnam Shrimp Sector, 2008-2017. Available online: www.vasep.com.vn (accessed on 4 May 2019).

14. Nguyen, T.; Hong, K.; Thu, T.T.; Lebailly, N.P.; Azadi, H. Economic challenges of the export-oriented aquaculture sector in Vietnam. J. Appl. Aquacult. 2019, 17-23. [CrossRef]

15. Hong, T.K.N.; Phan, T.T.H.; Tran, T.N.T.; Philippe, L. Vietnam's fisheries and aquaculture development's policy: Are exports performance targets sustainable? Ocean. Fish. 2017, 5, 555667. [CrossRef]

16. Dao, T. Vietnam Sets Goals for Shrimp Industry through 2025, Seafood Source, 2018. Available online: https://www.seafoodsource.com/news/supply-trade/vietnam-sets-goals-for-shrimpindustry-through-2025 (accessed on 4 March 2019).

17. Urch, M. Vietnamese Shrimp Producers in Danger of Losing Export Markets; Seafood Source; 2017. Available online: https://www.seafoodsource.com/features/vietnamese-shrimp-producers-in-danger-of-losing-exportmarkets (accessed on 4 March 2019).

18. Duc, P.M.; Hoa, T.T.T.; Phuong, N.T.; Bosma, R.H.; Hien, H.V.; Tuan, T.N. Virus diseases risk-factors associated with shrimp farming practices in rice-shrimp and intensive culture systems in Mekong Delta Vietnam. Int. J. Sci. Res. Pub. 2015, 5, 2250-3153.

19. Kearns, M.G. Shrimp Diseases Continue to Vex Farmers in Vietnam; Seafood Source; 2017. Available online: https://www.seafoodsource.com/news/aquaculture/shrimp-diseases-vex-farmers-in-vietnam (accessed on 4 March 2019).

20. Chia, T.T.K.; Clausena, J.H.; Vanb, P.T.; Tersbølc, B.; Dalsgaard, A. Use practices of antimicrobials and other compounds by shrimp and fish farmers in Northern Vietnam. Aquac. Rep. 2017, 7, 40-47.

21. Hasson, K.; Lightner, D.; Poulos, B.; Redman, R.; White, B.; Brock, J. Taura syndrome in P. vannamei: Demonstration of a viral etiology. Disrib. Aquat. Organ. 1995, 23, 115-126. [CrossRef]

22. Dhar, A.K.; Cowley, J.A.; Hasson, K.W.; Walker, P.J. Genomic organization, biology, and diagnosis of taura syndrome virus and yellowhead virus of penaeid shrimp. Adv. Virus Res. 2004, 63, 353-421. [PubMed]

23. Sittidilokratna, N.; Dangtip, S.; Cowley, J.A.; Walker, P.J. RNA transcription analysis and completion of the genome sequence of yellow head nidovirus. Virus Res. 2008, 136, 157-165. [CrossRef] 
24. Lightner, D.V. Virus diseases of farmed shrimp in the Western Hemisphere (the Americas): A review. J. Invertebr. Pathol. 2011, 106, 110-130. [CrossRef] [PubMed]

25. FAO/MARD. FAO Fisheries and Aquaculture Report No. In Proceedings of the Technical Workshop on Early Mortality Syndrome (EMS) or Acute Hepatopancreatic Necrosis Syndrome (AHPND) of Cultured Shrimp (under CP/VIE/ 3304), Hanoi, Vietnam, 25-27 June 2013.

26. Tran, N.; Bailey, C.; Wilson, N.; Phillips, M. Governance of global value chains in response to food safety and certification standards: The case of shrimp from Vietnam. World Dev. 2013, 45, 325-336. [CrossRef]

27. Initiative on Foreign Affairs and International Relations (IFAIR). Strategies for Sustainable Shrimp Aquaculture in Vietnam: The Example of Integrated Shrimp-Mangrove Farming and Organic Certification. 2015. Available online: http://ifair.eu/strategies-sustainable-shrimp-aquaculture/ (accessed on 4 February 2019).

28. Ministry of Agricultural and Rural Development (MARD). Vietnam Shrimp Farming Conference. In Proceedings of the Ministry of Agricultural and Rural Development Internal Meeting, Bac Lieu, Province, Vietnam, 24-26 June 2016.

29. De Silva, S.S.; Soto, D. Climate change and aquaculture: Potential impacts, adaptation and mitigation. In Climate Change Implications for Fisheries and Aquaculture: Overview of Current Scientific Knowledge; FAO Fisheries and Aquaculture Technical Paper, (530); Cochrane, K., De Young, C., Soto, D., Bahri, T., Eds.; FAO: Rome, Italy, 2009; pp. 151-212.

30. World Fisheries Council (WFC). Economics of Adaptation to Climate Change-the Case Study of Vietnam's Aquaculture Sector; Centre for Marine Life Conservation and Community Development, Can Tho University-Sub-National Institute for Agricultural Planning and Projection, World Fish Centre: Penang, Malaysia, 2009.

31. World Bank. Vietnam-Economics of Adaptation to Climate Change. Retrieved from Washington, DC: 2010. Available online: http://documents.worldbank.org/curated/en/563491468149078334/Vietnam-Economicsofadaptation-to-climate-change (accessed on 4 May 2019).

32. Abery, N.W.; Hoang, T.M.; Phuong, N.T.; Jumnongsong, S.; Nagothu, U.S.; Tung, P.B.V.; Silva, S.S.D. Vulnerability and Adaptation to Climate Change and Extreme Climate Events: The Case of Improved Extensive Shrimp Farming in Ca Mau and Bac Lieu Provinces, Vietnam: Analysis of Stakeholder Perceptions; Retrieved from Aqua Climate; NACA Action Aid, CRES: Abuja, Nigeria, 2010.

33. Tendencia, E.A.; Verreth, J.A.J. Temperature fluctuation, low salinity, water microflora: Risk factors for WSSV outbreaks in Penaeus monodon. Is. J. Aquac. Bamidgeh 2011, 63, 63-548.

34. Waibel, H.P.T.H.; Völker, M. Farmers' Perceptions of and Adaptations to Climate Change in Southeast Asia: The Case Study from Thailand and Vietnam; Lipper, L., McCarthy, N., Zilberman, D., Asfaw, S., Branca, G., Lipper, L., McCarthy, N., Zilberman, D., Asfaw, S., Branca, G., Eds.; Springer: Cham, Switzerland, 2017; Volume 52.

35. Casani, S.; Leth, T.; Knchel, S. Water reuse in a shrimp processing line: Safety considerations using a HACCP approach. Food Control. 2006, 17, 540-550. [CrossRef]

36. Khang, P. Challenges to Shrimp Production in the Bentre Province, Vietnam. Master's Thesis, International Fisheries Management, Department of Social Fisheries and Management, University of Tromso, Tromso, Norway, 2008; p. 25.

37. Anh, P.T.; Kroeze, C.; Bush, S.R.; Mol, A.P.J. Water pollution by intensive brackish shrimp farming in south-east Vietnam: Causes and options for control. Agric. Water Manag. 2010, 97, 872-882. [CrossRef]

38. Anh, P.T.; Bush, S.R.; Mol, A.P.J.; Kroeze, C. The Multilevel environmental Governance of Vietnamese aquaculture: Global certification, national standards, local cooperatives. J. Environ. Policy Plan. 2011, 13, 373-397. [CrossRef]

39. Nguyen, C.T.A.; Jolly, C.M. Macro-economic and product challenges facing the Vietnamese pangasius industry. Rev. Fish. Sci. Aquac. 2017. [CrossRef]

40. Environmental Justice Foundation (EJF). Risky Business: Vietnamese Shrimp Aquaculture-Impacts and Improvements; Environmental Justice Foundation: London, UK, 2003.

41. Hue, L.T.V.; Scott, S. Coastal livelihood transitions: Socio-economic consequences of changing mangrove forest management and land allocation in a commune of central Vietnam. Geogr Res. 2008, 46, 62-73.

42. Soo Kum Lin, J. Sustainability of Intensive Shrimp Farming: A Case in NinhThuan, Vietnam. Master's Thesis, Lund University, Lund, The Netherlands, 2006. 
43. Lee, J.; Gereffi, G.; Beauvais, J. Global value chains and agrifood standards: Challenges and possibilities for small holders in developing countries. Proc. Natl. Acad. Sci. USA 2012, 109, 12326-12331. Available online: www.pnas.org/cgi/doi/10.1073/pnas.0913714108 (accessed on 4 May 2019).

44. Nabeshima, K.; Michida, E.; Nam, V.H.; Suzuki, A. Emergence of Asian GAPs and Its Relationship to Global, G.A.P.; Institute of Developing Economies (IDE), JETRO 3-2-2: Wakaba, Mihama-Ku, Chiba-Shi Chiba, Japan, 2015.

45. Ministry of Agriculture and Rural Development (MARD)—Bureau of Economic Cooperation and Rural Development. Success and challenges for the development of agricultural cooperatives. In Proceedings of the Workshop: Cooperatives and Economic Organizations in the Agricultural Sector, Ho Chi Minh, Vietnam, 2015.

46. Vietnam Cooperative Alliance. Overview of the development of cooperatives and agricultural cooperatives in Vietnam. In Proceedings of the Workshop Cooperatives and Economic Organizations in the Agricultural Sector, Ho Chi Minh, Vietnam, 2015.

47. UNEP. Sustainability Standards in the Vietnamese Aquaculture Sector; UNEP: Geneva, Switzerland, 2016.

48. Marschke, M.W.A. Is certification a viable option for small producer fish farmers in the global south? Insights from Vietnam. Mar. Policy 2014, 50, 197-206. [CrossRef]

49. Jonell, M.; Phillips, M.; Ronnback, P.; Troell, M. Eco-certification of farmed seafood: Will it make a difference? Ambio 2013, 42, 659-674. [CrossRef] [PubMed]

50. Viet Nam News, VIEP Shrimp Farming in Viet Nam: The Search for Sustainability. Available online: https:/vietnamnews.vn/economy/280699/shrimp-farming-in-viet-nam-the-search-for-sustainability. html\#SFzvKXhC62UjKFjK.97 (accessed on 4 May 2019).

51. International Trade Centre (ITC). The Impact of Private Standards in Global Value Chains; Literature Review Series on the Impacts of Private Standards: Part; ITC: Geneva, Switzerland, 2011; 41p.

52. Bjørndal, T.; Child, A.; Audun, L.; Dey, M.M. Value chain dynamics and small-scale sector: A summary of findings and policy recommendations for fisheries and aquaculture trade. Aquacult. Econ. Manag. 2015, 19, 148-173. [CrossRef]

53. De Janvry, A.; Sadoulet, E. Achieving success in rural development: Toward implementation of an integral approach. Agric. Econ. 2005, 32, 75-89. [CrossRef]

54. Daviron, B.; Gibbon, P. Global commodity chains and African export agriculture. J. Agric. Chang. 2002, 2, 137-161. [CrossRef]

55. Reardon, T.; Timmer, P.; Rerdegue, J. The rapid rise of supermarkets in developing countries: Induces organizational, institutional and technological change. Agric. Food Syst. 2004, 1, 168-183.

56. Trienekens, J.H. Agricultural value chains in developing countries: A framework for analysis. Inter. Food Agrbus. Man. 2011, 14, 51-84.

57. Rondot, P.M.H.; Collion, M.H. Agricultural producer Organizations: Their Contribution to Rural Capacity Building and Poverty; World Bank: Washington, DC, USA, 2001.

58. Seafood watch; Vietnam ponds; Seafood Watch Consulting Researchers; Monterey Bay Aquarium; 2017. Available online: https://www.seafoodwatch.org/-/m/sfw/pdf/reports/s/mba_seafoodwatch_farmedvietnam_ shrimp.pdf (accessed on 4 July 2019).

59. Hai, T.N.P.; Minh, D.; Son, V.N.; Minh, T.H.; Nguyen, T.P. Innovation in seed production and farming of marine shrimp in Vietnam; World Aquaculture; 2015. Available online: //www.researchgate.net/publication/ 308202269 (accessed on 4 February 2019).

60. Shrimp News International, Vietnam, Viet-UC indoor system; 2015. Available online: https:// www.shrimpnews.com/FreeReportsFolder/NewsReportsFolder/VietnamVietUCfarm.html (accessed on 4 March 2019).

61. Avnimelech, Y.; De-Schryver, P.; Emmereciano, M.; Kuhn, D.; Ray, A.; Taw, N. Biofloc Technology for Super-Intensive Shrimp Culture, 2nd ed.; A Practical Guide Book; World Aquaculture Society: Baton, Rougge, LA, USA, 2009.

62. Diana, J.S. Aquaculture Production and Biodiversity Conservation. BioScience 2009, 59, 27-38. [CrossRef]

63. Cao, L.; Diana, J.S.; Keoleian, G.A.; Lai, Q. Life cycle assessment of Chinese shrimp farming systems targeted for export and domestic sales. Environ. Sci. Technol. 2011, 45, 6531-6538. [CrossRef] 
64. Samuel-Fitwi, B.; Schroeder, J.P.; Schulz, C. System delimitation in life cycle assessment (LCA) of aquaculture: Striving for valid and comprehensive environmental assessment using rainbow trout farming as a case study. Int. J. Life Cycle Assess. 2013, 18, 577-589. [CrossRef]

65. Wilfart, A.; Prudhomme, J.; Blancheton, J.P.; Aubin, J.L.C.A. Emergy accounting of aquaculture systems: Towards ecological intensification. J. Environ. Manag. 2013, 121, 96-109. [CrossRef] [PubMed]

66. Mungkung, R.T.; Aubbin, J.; Prihadi, T.H.; Slembrouck, J.; van der Werf, H.M.G.; Legendre, M. Life cycle assessment for environmentally sustainable aquaculture management: A case study of combined aquaculture systems for carp and tilapia. J. Clean Prod. 2013, 57, 249-256. [CrossRef]

67. Henriksson, P.J.G.; Rico, A.; Zhang, W.; Ahmad-al-Nahid, S.; Newton, R.; Phan, L.T.; Zhang, Z.; Jaithiang, J.; Dao, H.M.; Phu, T.M.; et al. Comparison of Asian aquaculture products by use of statistically supported life cycle assessment. Environ. Sci. Technol. 2015, 49, 14176-17183. [CrossRef]

68. Cao, L. Farming Shrimp for the Future: A Sustainability Analysis of Shrimp Farming in China. Ph.D. Thesis, Natural Resource and Environment, The University of Michigan, Ann Arbor, MI, USA, 2012; p. 146.

69. Bostock, J.; McAndrew, B.; Richards, R.; Jauncey, K.; Telfer, T.; Lorenzen, K.; Little, D.; Ross, L.; Handisyde, N.; Gatward, I.; et al. Aquaculture: Global status and trends. Philos. Trans. R. Soc. Bio. Sci. 2010, 365, $2897-2912$. [CrossRef] [PubMed]

70. Fletcher, R. WWF Calls for Intensification of Shrimp Production; The Fish Site; June 2017. Available online: https://thefishsite.com/articles/wwf-calls-for-intensification-of-shrimp-production (accessed on 4 April 2019).

71. Krummenauer, D.; Peixoto, S.; Cavalli, R.; Poersch, L.; Wilson, W. Super-intensive culture of white shrimp, L. vannamei, in a biofloc technology system in Southern Brazil at different stocking densities. J. World Aquacult. Soc. 2011, 42, 726-733. [CrossRef]

72. Ray, A.J.; Seaborn, G.; Vinatea, L.; Browdy, C.L.; Leffler, J.W. Effects of biofloc reduction on microbial dynamics in minimal-exchange, superintensive shrimp (L. vannamei) culture systems. J. World Aquacult. Soc. 2012, 43, 790-801. [CrossRef]

73. Ray, A.J.; Lewis, B.L.; Browdy, C.L.; Leffler, J.W. Suspended solids removal to improve shrimp (L. vannamei) production and an evaluation of a plant-based feed in minimal-exchange, superintensive culture systems. Aquaculture 2010, 299, 89-98. [CrossRef]

74. Ray, A.J.; Seaborn, G.; Wilde, S.B.; Leffler, J.W.; Lawson, A.; Browdy, C.L. Characterization of microbial communities in minimal-exchange, intensive aquaculture systems and the effects of suspended solids management. Aquaculture 2010, 310, 130-138. [CrossRef]

75. Ostrensky, A.; Wasielesky, W., Jr. Acute toxicity of ammonia to various life stages of the Sao Paulo shrimp, Penaeus paulensis Perez-Farfante. Aquaculture 1995, 132, 339-347. [CrossRef]

76. Van Wyk, P.; Scarpa, J. Water quality requirements and management. In Scarpa, Farming Marine Shrimp in Recirculating Freshwater Systems; Van Wyk, P., Davis-Hodgkins, M., Laramore, R., Main, K., Mountain, J., Eds.; Florida Department of Agriculture and Consumer Services: Tallahassee, FL, USA, 1999; pp. 128-138.

77. Lin, Y.C.; Chen., J.C. Acute toxicity of ammonia on Litopenaeus vannamei Boone juveniles at different salinity levels. J. Exp. Mar. Biol Ecol. 2001, 259, 109-119. [CrossRef]

78. Timmons, M.B.; Ebeling, J.M.; Wheaton, F.W.; Summerfelt, S.T.; Vinci, B.J. Recirculating Aquaculture Systems, 2nd ed.; NRAC Publication: Ithaca, NY, USA, 2002; Volume 1.

79. Read, P.; Fernandes, T. Management of environmental impacts of marine aquaculture in Europe. Aquaculture 2003, 226, 139-163. [CrossRef]

80. Piedrahita, R.H. Reducing the potential environmental impact of tank aquaculture effluents through intensification and recirculation. Aquaculture 2003, 226, 35-44. [CrossRef]

81. Cohen, J.; Samocha, T.M.; Fox, J.M.; Lawrence, A.L. Characterization of water quality factors during intensive raceway production of juvenile L. vannamei using limited discharge and biosecure management tools. Aquac. Eng. 2005, 32, 425-442. [CrossRef]

82. Krummenauer, D.; Samocha, T.; Poersch, L.; Lara, G.; Wasielesky, W. The reuse of water on culture of Pacific white shrimp, L. vannamei; in BFT system. J. Aquac. Soc. 2014, 45, 3-14. [CrossRef]

83. Thakur, D.P.; Lin, C.K. Water quality and nutrient budget in closed shrimp (Penaeus monodon) culture systems. Aquac. Eng. 2003, 27, 159-176. [CrossRef]

84. Crab, R.; Kochva, M.; Verstraete, W.; Avnimelech, Y. Bio-flocs technology application in overwintering of tilapia. Aquac. Eng. 2009, 40, 105-112. [CrossRef] 
85. McIntosh, R.P. Changing paradigms in shrimp farming: III. Pond design and operation considerations. Glob. Aquac. Advocate 2000, 3, 42-45.

86. Moss, S.M.; Arce, B.J.; Argue, C.A.; Otoshi, F.; Calderon, R.O.; Tacon, A.G.J. Greening of the blue revolution: Efforts toward environmentally responsible shrimp culture. In The New Wave: Proceedings of the Special Session on Sustainable Shrimp Culture, Aquaculture; Browdy, C.L., Jory, D.E., Eds.; The World Aquaculture Society: Baton Rouge, LA, USA, 2001; pp. 1-19.

87. Samocha, T.M.; Patnaik, S.M.; Speed, A.M.; Ali, J.; M.Burger, R.V.; Almeida, Z.; Ayub, M.; Harisanto, A.; Horowitz; Brock., D.L. Use of molasses as carbon source in limited discharge nursery and grow-out systems for L. vannamei. Aquac. Eng. 2007, 36, 184-191. [CrossRef]

88. Weirich, C.R.; Browdy, C.L.; Bratvold, D.; McAbee, B.J. Preliminary characterization of a prototype minimal exchange super-intensive shrimp production system. In Proceedings of the IV International Conference on Recirculating Aquaculture, Virginia Tech University, Blacksburg, VA, USA, 20-22 August 2002; pp. 255-270.

89. Schneider, O.; Sereti, V.; Eding, E.H.; Verreth, J.A.J. Molasses as C source for heterotrophic bacteria production on solid fish waste. Aquaculture 2006, 261, 1239-1248. [CrossRef]

90. Schryver, P.D.; Crab, R.; Defoirdt, T.; Boon, N.; Verstraete, W. The basics of bio-flocs tech nology: The added value for aquaculture. Aquaculture 2008, 277, 125-137. [CrossRef]

91. Peixoto, S.; Wasielesky, W.J.; Louzada, L. Comparative analysis of pink shrimp, Farfantepenaeus paulensis, and pacific white shrimp, L. vannamei, culture in extreme Southern Brazil. J. Appl. Aquac. 2003, 14, 101-112. [CrossRef]

92. Engle, C.R.; Boyd, C.E.; Paungkaew, D.; Viriyatum, R.; Tinh, H.Q.; Minh, H.N. Economics of sustainable intensification of aquaculture: Evidence from shrimp farms in Vietnam and Thailand. J. World Aquac. Soc. 2017, 48, 227-239. [CrossRef]

93. Otoshi, C.A.; Scott, M.S.; Naguwa, F.C.; Moss, S.M. Shrimp behavior may affect culture performance at super-intensive stocking densities. Glob. Aquac. Advocate 2007, 2, 67-69.

94. Ray, A.J. Biofloc Technology For Super-Intensive Shrimp Culture. In Biofloc Technology: A Practical Guide, 2nd ed.; Avnimelech, Y., De-Schryver, P., Emmereciano, M., Kuhn, D., Ray, A., Taw, N., Eds.; Aorld Aquaculture Society, Louisiana State University: Baton Rouge, LA, USA, 2012.

95. Hanson, T.R.; Posadas, B.C.; Samocha, T.M.; Stokes, A.D.; Losordo, T.M.; Browdy, C.L. Economic factors critical to the profitability of super-intensive biofloc recirculating shrimp production systems for marine shrimp L. vannamei. The Rising Tide. In Special Session on Sustainable Shrimp Farming; Browdy, C.L., Jory, D.E., Eds.; World Aquaculture World Aquaculture Society: Baton Rouge, LA, USA, 2009.

96. Browdy, C.L.; Stokes, A.D.; McAbee, B.; Atwood, H.; Wasielesky, W.; Leffler, J. Insights into the functional roles of major components of microbial communities in zero exchange super-intensive shrimp systems. In Aquaculture America 2006 Book of Abstracts; The World Aquaculture Society: Baton Rouge, LA, USA, 15 February 2006.

97. Azim, M.E.; Little, D.C.; Bron, J.E. Microbial protein production in activated suspension tanks manipulating the C:N ratio in feed and the implications for fish culture. Biores. Tech. 2008, 99, 3590-3599. [CrossRef] [PubMed]

98. Burford, M.A.; Thompson, P.J.; McIntosh, R.P.; Bauman, R.H.; Pearson, D.C. Nutrient and microbial dynamics in high-intensity, zero-exchange shrimp ponds in Belize. Aquaculture 2003, 219, 393-411. [CrossRef]

99. Suzuki, A.; Nam, V.H. Status of Costly Port. Rejection: A Case from Vietnamese Frozen Seafood Export Industry; IDE Paper Number 395; IDE: Jetro Wakaba, Michama-Ku Chiba Shi Chiba, Japan, 2013.

100. Khoi, L.N.D. Description of the Pangasius Value Chain in Vietnam; CAS Discussion Paper, No.; Centre for ASEAN Studies (CAS) and Centre for International Management and Development Antwerp (Cimda): Antwerp, Belgium, 2007.

101. Loc, N.T.T.; Hang, N.T. Current Situation and prospects of Cooperatives in Vietnam's; Agricultural Sector; Fruit and Vegetable Research Institute: Hanoi, Vietnam, 2015.

102. Van Nghiem, N. Agricultural Cooperatives in Vietnam. Proccedigs of the FFTC-NACF International Seminar on Agricultural Cooperatives in Asia Innovations and Opportunities in the 21th Century, Seul, Korea, 11-15 September 2006. 
103. Van Nghiem, N. Agricultural Cooperatives in Vietnam: Innovations and Opportunities; Department of Cooperatives and Rural Development; Ministry of Agriculture and Rural Development; Vietnam, 01-15: 2008. Available online: http://www.fftc.agnet.org/library.php?func=view\&id=20110726095506\&type_id=4 (accessed on 4 March 2019).

104. Knapp, J.G. Cooperative Expansion through Horizontal Integration. Am. J. Agric. Econ. 1950, 32, $1031-1047$. [CrossRef]

105. Ha, T.T. T Global and local governance of shrimp farming in the Mekong Delta, Vietnam. Ph.D. Thesis, Wageningen University, Wageningen, The Netherlands, 2012.

106. Potts, J.; Lynch, M.; Wilkings, A.; Huppé, G.; Cunningham, M.; Voora, V. The State of Sustainability Initiatives: Standards and the Green Economy; International Institute of Sustainable Development: Winnipeg, MB, Canada, 2014.

107. Southern Centre for Agricultural Policy and Strategy (SCAP). Baseline Survey Report on Shrimp Value Chain and Gender Transformation in Soc Trang Province for the Project. Gender Transformative and Responsible Agribusiness Investments in South East Asia (GRAISEA); International Collaborating Centre for Aquaculture and Fisheries Sustainability-ICAFIS-Vietnam Fisheries Society (VINAFIS): Hanoi, Vietnam, 2015.

108. Coles, C.; Mitchell, J. Working Together- Horizontal Coordination as an Upgrading Strategy. In Markets and Rural Poverty: Upgrading in Value Chains; Mitchell, J., Coles, C., Eds.; Earths can: Washington, DC, USA, 2011.

109. Nguyen, T.B.T. Good aquaculture practices (VietGAP) and sustainable aquaculture development in Viet Nam. In Resource Enhancement and Sustainable Aquaculture Practices in Southeast Asia: Challenges in Responsible Production of Aquatic Species, Proceedings of the International Workshop on Resource Enhancement and Sustainable Aquaculture Practices in Southeast Asia 2014 (RESA); Romana-Eguia, M.R.R., ParadoEstepa, F.D., Salayo, N.D., Lebata-Ramos, M.J.H., Eds.; Aquaculture Dept., Southeast Asian Fisheries Development Center: Tigbauan, IL, Philippines, 2014; pp. 85-92.

110. FAO. The State of World Fisheries and Aquaculture; Food and Agriculture Organization of the United Nation: Rome, Italy, 2012.

111. Aalimahmoudi, M.; Azarm, H.M.; Mohamadi, Y. Biofloc new technology and shrimp disease in super-intensive aquaculture. Int. J. Fish Aquatic Res. 2017, 2, 17-21. Available online: www.fishjournals.com (accessed on 5 April 2019).

112. Taw, N. Biofloc as biosecurity: A possible solution in preventing shrimp disease. In Proceedings of the World Aquaculture, Adelaide, Australia, 7-11 June 2014.

113. Ekasari, J.A.D.; Waluyo, S.H.; Bachtiar, T.; Surawidjaja, E.H.; Bossier, P.; De Schryver, P. The size of biofloc determines the nutritional composition and the nitrogen recovery by aquaculture animals. Aquaculture 2014, 426-427, 105-111. [CrossRef]

114. Crab, R. Biofloc technology: An integrated system for the removal of nutrients and simultaneous production of feed in aquaculture. Ph.D. Thesis, Ghent University, Brussels, Belgium, 2010; p. 178.

115. Wang, J.C.; Chang, P.S.; Chen, H.Y. Differential time-series expression of immune-related genes of Pacific white shrimp (Litopenaeus vannamei) in response to dietary inclusion of $\beta-1,3$-glucan. Fish. Shell Immun 2008, 24, 113-121. [CrossRef] [PubMed]

116. Joffre, M.O.; Bosma, R.H. Typology of shrimp farming in Bac Lieu Province, Mekong Delta, using multivariate statistics. Agric. Ecosyst. Environ. 2008, 132, 153-159. [CrossRef]

117. Hoa, T.T.T.; Zwart, M.P.Z.; Phuong, N.T.; Oanh, D.T.H.; de Jong, M.C.M.; Vlak, J.M. Mixed-genotype WSSV infections of shrimp are inversely correlated with disease outbreaks in ponds. J. Gen. Virol. 2011, 92, 675-680. [CrossRef]

118. Dieu, B.T.M.; Vlak, J.M.; Zwart, M.P. Effects of extensive and intensive shrimp farming on the generic composition of white spot syndrome virus population. In Diseases in Asian Aquaculture VII; Bondad-Rcantaso, M.G., Johnes, J.B., Corsin, F., Aoki, T., Eds.; Asian Fisheries Society: Selangor, Malaysia, 2011.

119. Tendencia, E.A.; Bosma, R.H.; Verreth, J.A.J. White spot syndrome virus (WSSV) risk factors associated with shrimp farming practices in polyculture and monoculture farms in the Philippines. Aquaculture 2011, 311, 87-93. [CrossRef]

120. Be, T.T.; Clayton, H.; Brennan, D. Socioeconomic characteristics of rice-Shrimp farms in the study region. In Rice-Shrimp Farming in the Mekong Delta: Biophysical and Socioeconomic Issues; Preston, N., Clayton, H., Eds.; ACIAR Technical Reports No. 52e; ACIAR: Canaberra, Australia, 2003; 170p. 
121. Hoa, T.T.T.; Zwart, M.P.; Phuong, N.T.; Vlak, J.M.; Jong, M.C.M.D. Transmission of white spot syndrome virus in improved-extensive and semi-intensive shrimp production systems: A molecular epidemiology study. Aquaculture 2011, 313, 7-14. [CrossRef]

122. Hai, N.V.; Hao, N.V.; Abery, N.W.; Silva, S.S.D. Perceived Impacts and Adaptation to Climate Changes in Small-Scale Shrimp Farming in Ca Mau Province; Retrieved from Research Institute for Aquaculture No.2 \& NACA: HCM City, Vietnam, 2011.

123. Quach, A.V. Shrimp farming vulnerability and adaptation to climate change in Ca Mau, VietNam. Ph.D. Thesis. Murdoch University, Perth, Australia, 2018; p. 199.

124. Quach, A.; Murray, F.; Morrison-Saunders, A. The Vulnerability of Shrimp Farming Income to Climate Change Events: A Case Study in Ca Mau, Vietnam. Int. J. Clime Chang. Strat Manag. 2017, 9, pp. 261-280. Available online: http:/www.emeraldinsight.com/doi/pdfplus/10.1108/IJCCSM-05\&\#x2013;2015\&\#x2013; 0062 (accessed on 4 March 2019).

125. Quagrainie, K. Profitability of Indoor Production of Pacific White Shrimp (Litopenaeus vannamei): A Case Study of the Indiana Industry; EC-797_W IISG-15-005; Purdue Extension Service: West Lafayette, IN, USA, 2015.

126. Viet Fish, Zero Water Exchange Super-Intensive Indoor Shrimp Production. 2017. Available online: http://vietfishmagazine.com/aquaculture/zero-water-exchange-super-intensive-indoor-shrimpproduction.html (accessed on 4 May 2019).

127. Ministry of Finance (MoFi). Decision 04/QD-BTS Regarding Regulations for Environment Management in Semi and Intensive Farming Areas. Ministry of Fishery: Hanoi, Vietnam, 2002.

128. Little, D.C.; Bush, R.S.; Belton, B.; Phuong, M.T.; Young, J.A.; Murray, F.J. White fish wars: Pangasius politics and consumer confusion in Europe. Mar. Policy 2012, 36, 738-745. [CrossRef]

129. Waite, R.; Beridge, M.; Brummett, R.; Castine, S. Improving Productivity and Environmental Performance of Aquaculture. 2014. Available online: https://www.wri.org/sites/default/files/wrr_installment_5_improving productivity_environmental (accessed on 4 February 2019).

130. Taw, N. Shrimp farming in biofloc system: Review and recent developments. In Proceedings of the World aquaculture conference, Adelaide, Australia, 7-11 June 2014.

131. Quarto, A. The Rise and Fall of the Blue Revolution. East Africa Wildlife Society's Magazine SWARA, October-December 1998; pp. 16-21.

132. Centre for the Promotion of Imports from Developing Countries. The Vietnamese Seafood Sector: A VALUE Chain Analysis. Available online: http://edepot.wur.nl/237935 (accessed on 4 February 2019). 